\title{
Computational Fluid Dynamic Simulation and Validation Bed Expansion of Three-Phase Co- Current Fluidized Bed
}

\author{
Zainab Abdulameer Joodi ${ }^{\mathrm{a}}$ Zaidoon M. Shakoor ${ }^{\mathrm{a}}$ Amer A. Abdul- Rahman ${ }^{\mathrm{a}}$ \\ ${ }^{a}$ Chemical Engineering Department, University of Technology, Baghdad, Iraq
}

Zainababed13@gmail.com ㅁ﹎zaidoon@yahoo.com ameraa1972@yahoo.com

\begin{abstract}
The bed expansion of gas-liquid-solid co-current fluidized bed is studied in the present work. Experimental work is carried out using Perspex column having $0.092 \mathrm{~m}$ inner diameter, $2 \mathrm{~m}$ height. Kerosene and air are used as continuous and dispersed phases, respectively. Glass beads having 0.0038 $\mathrm{m}$ diameter and $2247 \mathrm{~kg} / \mathrm{m}^{3}$ density and catalyst particles having $0.0025 \mathrm{~m}$ diameter and $2070 \mathrm{~kg} / \mathrm{m}^{3}$ density, which were taken from the kerosene hydrotreating reactor that is located in Al-Daura Refinery, are used as the solid phase.
\end{abstract}

The Computational fluid dynamic CFD results of dynamic characteristics were obtained based on simulation using commercial CFD codes and ANSYS FLUENT 16.0 have been used for validation, by comparing the simulation and experimental results. Eulerian approach for flow of granular multiphase is utilized to predict the performance of the three-phase co-current fluidized bed.

The results are indicated that the height of the expanded bed is having a strong function of liquid velocity, which increases as the liquid velocity increases too.

Keywords: Bed expansion, Three-phase co-current fluidized bed, Hydrodynamics study, Computational fluid dynamic.

\section{Introduction}

Fluidization is one of the important industry processes happens when gas and liquid are moved up during the particles of the bed in which the granular material is converted from the stagnant state to the moving state. At this point, when the gas or liquid stream is passed from the bottom of the bed; it moves upward through a bed by means of empty spaces between the granular materials [1]. Fluidized bed reactor has wide industrial-applications compared with fixed bed; thus, it has become the multilateral fluid-solid communicating apparatus in metallurgical, biochemical and chemical industries. Several applications of fluidization has began to be used for developing petroleum industry with catalytic cracking, coating metals with plastic, drying of solid materials, transportation, heating, coal gasification, synthesis reactions, combustion and incineration, carbonization and gasification, roasting of sulphide ores and reduction of iron oxide [2].

Computational fluid dynamic (CFD) is a branch of fluid mechanics that utilizes different algorithms and numerical methods to calculate and analyze fluid flow problems [3]. Also, it has dedicated numerical procedures to predict related phenomena, such as mass transfer, fluid flow, reactions of chemical and heat transfer, with the capability of solving the mathematical equations that decide these processes utilizing a computer-based simulation. The CFD is mainly based on Navier-Stokes equations [4] and the numerical approaches that are used for solving nonlinear 
differential equations for pre-defined boundary conditions and geometries to linearized form.

A simulation investigation has carried out for three-phase fluidized bed system by Bahary et al. [5] using Eulerian approach for multi-phase granular flow, where the phase of gas was considered the particulate phase with $4 \mathrm{~mm}$ diameter. The Eulerian approach for multi-fluid has been used by Mitra-Majumdar et al [6]to study a threephase system in a bubble column. They used the correlation of modified drag force between the gas and liquid phase to determine the influence of solid material, and between the liquid and solid particles to determine the influence of gas bubbles. The $\mathrm{k}-\varepsilon$ turbulence model has been taken for turbulence and used to treat the influence of bubbles on a turbulent liquid. Yali Tang et.al., [7]conducted a numerical simulation for studying the dynamic of gas flow through spherical, suspended particles. They have used the immersed boundary method for simulations. In this study, the Reynolds number, volume fraction of the solids phase and density ratio of gas/particle were taken in consideration. The influence of solid particle motion on the drag force of gassolid is analyzed; the simulation results were used in the drag correlation, which was derived from simulations of stationary particles. The effect of motion is identified by the granular temperature, which is an outcome from velocity fluctuation of the particle.

In this paper the influence of superficial inlet velocities of gas and liquid on the bed expansion of solid beds is studied.

\section{Experimental Work}

The experimental work was carried out in the Perspex column that has $0.092 \mathrm{~m}$ I.D. and $2 \mathrm{~m}$ height. Kerosene and air were used as liquid and gas phase, respectively. The glass beads with diameter $0.38 \mathrm{~cm}$ and catalyst particles with diameter $0.25 \mathrm{~cm}$ were used as solid phase. The Figure 1 shows a schematic diagram and the laboratorybased set-up of the used/designed rig.

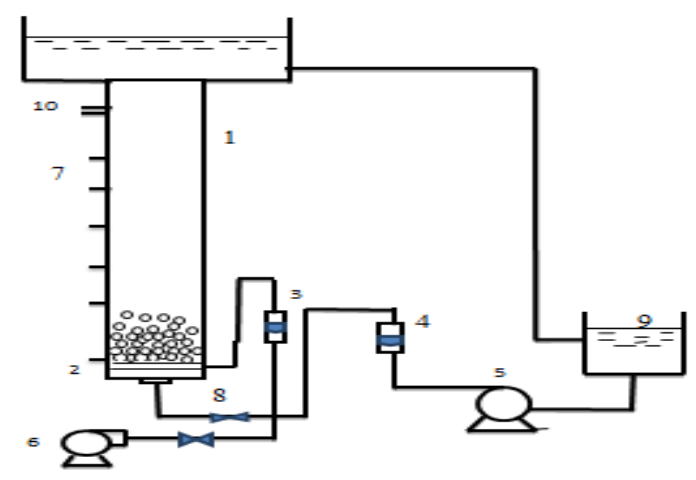

Figure 1: A schematic diagram of experimental set-up

1. Perspex column. 2. Distributor. 3. Gas Rotameter.

4. Liquid Rotameter. 5. Liquid Pump. 6. Air compressor.

7. Pressure Taps. 8. Needle valve. 9. Reservoir.

10. Vent. 
The distributor was installed in the bottom of the column in the test section. This distributor is designed in such a pattern that a uniform distribution of fluid, liquid and gas phase can be easily obtained in this column.

The distributor contains 40 evenly spaced circular holes for gas and 60 evenly spaced circular holes for liquid, each with a diameter of $2 \mathrm{~mm}$.

\section{Working on CFD code}

Bakker [8] indicated that all commercial packages of CFD contain the developing user input simulation parameters, studying and analysis the process results. So, all packages of CFD codes comprise essential stages, which are preprocessing, solver and post-processing.

\section{Pre-processing}

The Pre-processing contains three steps; the first step is drawing the geometry of the problem under study for computational domain; the second step is dividing the geometry to a smaller number of grids for domain that non-overlapping sub domains; the final step is specifying the suitable boundary condition at cells.

\section{solver}

FLUENT uses the finite-volume method (FVM) and different physical models (incompressible, compressible, viscous, laminar and turbulences, etc.) to solve the governing equations of fluid. The governing equations are non-linear; hence a large number of solution iterations are performed by the solver until obtaining a converged solution.

\section{post-processing}

In this step, the results are analyzed and displayed on the predicted flow data using several forms, such as X-Y plots, vector plots, contour plot, 2D and 3D plots, animations, etc.

\section{Governing Equations of Multifluid Model}

The CFD simulation of the three-phase co-current gas-liquid-solid fluidized bed is carried out using ANSYS FLUENT 16.0 software and employing the governing equations for both mass and momentum. A multiphase Eulerian model is applied to both mass and momentum equations of fluid liquid or/and gas and solid phases, as in the following paragraphs[9]:

\section{Continuity Equation}

$\frac{\partial}{\partial \mathrm{t}}\left(\varepsilon_{\mathrm{k}} \rho_{\mathrm{k}}\right)+\nabla\left(\rho_{\mathrm{k}} \varepsilon_{\mathrm{k}} \mathrm{u}_{\mathrm{k}}\right)=0$

Where $\varepsilon_{\mathrm{k}}$ is the volume fraction and $\rho_{\mathrm{k}}$ is the density of each phase $(\mathrm{k}=\mathrm{g}, 1, \mathrm{~s})$, where the summation of three phases volume fractions is equal to one:

$\varepsilon_{\mathrm{g}}+\varepsilon_{\mathrm{l}}+\varepsilon_{\mathrm{s}}=1$ 
Journal of University of Babylon for Engineering Sciences, Vol. (26), No. (6): 2018.

\section{Momentum Equation:}

The momentum equation of the three phases is:-

$\frac{\partial}{\partial \mathrm{t}}\left(\varepsilon_{\mathrm{k}} \rho_{\mathrm{k}}\right)+\nabla\left(\rho_{\mathrm{k}} \varepsilon_{\mathrm{k}} \mathrm{u}_{\mathrm{k}} \mathrm{u}_{\mathrm{k}}\right)=-\varepsilon_{\mathrm{k}} \nabla \mathrm{P}+\nabla\left(\varepsilon_{\mathrm{k}} \mu_{\mathrm{eff}, \mathrm{k}}\left(\nabla \mathrm{u}_{\mathrm{k}}+\left(\nabla \mathrm{u}_{\mathrm{k}}\right)^{\mathrm{T}}\right)\right)+\rho_{\mathrm{k}} \varepsilon_{\mathrm{k}} \mathrm{g}+\mathrm{M}_{\mathrm{i}, \mathrm{k}}$

Where $\mathrm{u}_{\mathrm{k}}, \mu_{\text {eff }}$ and $\mathrm{g}$ are the phase velocity, the phase effective viscosity and gravity vector respectively. $\mathrm{P}$ is the static pressure, however, the term of solid phase momentum in Equation 3 contains an additional pressure of solid because of solid collisions. The second term is the stress tensor; the $\mathrm{M}_{\mathrm{i}, \mathrm{k}}$ refers to the inter-phase force of each phase (gas, liquid and solid). All equations are solved using ANSYS FLUENT, the finite volume solver is used to solve complex fluid flow problems.

\section{Closure Law for Turbulence:}

The effective liquid phase viscosity is calculated using the following equation.

$$
\mu_{\mathrm{eff}, \mathrm{l}}=\mu_{\mathrm{l}}+\mu_{\mathrm{T}, \mathrm{l}}+\mu_{\mathrm{t}, \mathrm{g}}+\mu_{\mathrm{t}, \mathrm{s}}
$$

Where $\mu_{1}$ and $\mu_{\mathrm{T}, 1}$ are the liquid viscosity and the liquid phase turbulence viscosity, which is calculated using $(\mathrm{k}-\varepsilon)$ model, as follow:-

$\mu_{T l}=C_{\mu} \rho_{l} \frac{k^{2}}{\varepsilon}$

Where $\mathrm{k}$ and $\varepsilon$ are calculated from the differential transfer equations of kinetic energy and dissipation rate in the turbulence regime. Also $\mu_{\mathrm{tg}}$ and $\mu_{\mathrm{t}, \mathrm{s}}$ are the gas and solid phase viscosity caused by turbulence, for which equations were introduced by Sato [10].

$\mu_{t g}=C_{\mu p} \rho_{l} \varepsilon_{g} d_{b}\left|u_{g}-u_{l}\right|$

$\mu_{t s}=C_{\mu p} \rho_{l} \varepsilon_{s} d_{p}\left|u_{s}-u_{l}\right|$

\section{Inter-phases Drag Force:}

When there are two fluids with unequal amounts in fluid-fluid flows, the predominant fluid should be considered the primary fluid and other is the secondary phase, where the sparser fluid is droplets or bubbles forms. The exchange coefficient equations for (gas-liquid) or (liquid-liquid) are [9]:

$K_{p q}=\frac{\alpha_{q} \alpha_{p} \rho_{p} f}{\tau_{p}}$

That $\tau_{p}$ is the particulate relaxation time and defined as follows:

$$
\begin{gathered}
\tau_{p}=\frac{\rho_{p} d_{p}{ }^{2}}{18 \mu_{q}} \\
f=\frac{C_{D} R_{e}}{24}
\end{gathered}
$$


Journal of University of Babylon for Engineering Sciences, Vol. (26), No. (6): 2018.

$$
\begin{array}{ll}
C_{D}=\frac{24\left(1+0.15 R_{e}^{0.687}\right)}{R_{e}} & \text { for } R_{e} \leq 1000 \\
C_{D}=0.44 & \text { for } R_{e}>1000
\end{array}
$$

The Reynolds number for the primary phase (q) and secondary phase (p) are computed using Equation 13 and 14 respectively.

$R_{e}=\frac{\rho_{q} d_{p}\left|u_{p}-u_{q}\right|}{\mu_{q}} \quad$ for the primary phase

$R_{e}=\frac{\rho_{r p} d_{r p}\left|u_{r}-u_{p}\right|}{\mu_{r p}} \quad$ for the secondary phase

Where $\mu_{r p}=\alpha_{p} \mu_{p}+\alpha_{r} \mu_{r}$ is the mixture viscosity of the $\mathrm{p}$ and $\mathrm{r}$ phases; the Gidaspow model is used for both solid-liquid and solid-air inter-phase in the present work, which is described as follow [11].

For $\alpha_{l} 1 \leq 0.8$

$K_{s l}=150 \frac{\alpha_{s}\left(1-\alpha_{l}\right) \mu_{l}}{\alpha_{l} d_{s}^{2}}+1.75 \frac{\rho_{l} \alpha_{s}\left|u_{s}-u_{l}\right|}{d_{s}}$

\section{Turbulence modeling} [12].

The turbulence kinetic energy can be computed transport equation, as follow

$$
\frac{\partial}{\partial t}(\rho k)+\frac{\partial}{\partial x_{i}}\left(\rho k u_{i}\right)=\frac{\partial}{\partial x_{j}}\left[\left(\mu+\frac{\mu_{t}}{\sigma_{k}}\right) \frac{\partial k}{\partial x_{i}}\right]+G_{k}+G_{b}-\rho \varepsilon-Y_{M}+s_{k} \ldots
$$

and

$\frac{\partial}{\partial t}(\rho \varepsilon)+\frac{\partial}{\partial x_{i}}\left(\rho \varepsilon u_{i}\right)=\frac{\partial}{\partial x_{j}}\left[\left(\mu+\frac{\mu_{t}}{\sigma_{\varepsilon}}\right) \frac{\partial \varepsilon}{\partial x_{j}}\right]+C_{1 \varepsilon} \frac{\varepsilon}{k}\left(G_{k}+C_{3 \varepsilon} G_{b}\right)-C_{2 \varepsilon} 3 \rho \frac{\varepsilon^{2}}{k}+s_{\varepsilon}(17)$

In the turbulence model and the equations mentioned above, $G_{k}$ refers to the kinetic energy that is generated based on the middle velocity gradients, $\mathrm{G}_{\mathrm{b}}$ represent the kinetic energy that generate the buoyancy and $\mathrm{Y}_{\mathrm{M}}$ is the contribution the diffusion of fluctuating in the turbulent to the total dispersal rate. $\sigma_{\mathrm{k}}$ and $\sigma_{\varepsilon}$ refer to the prandtl numbers of the turbulent kinetic energy and dispersal rate; $S_{\mathrm{k}}$ and $S_{\varepsilon}$ are user-defined source terms, and $\mathrm{C}_{\mu}$ is a constant. The $\mu_{\mathrm{t}}$ is the turbulent viscosity which is determined by combining $\mathrm{k}$ and $\varepsilon$ as in the following.

$$
\mu_{t}=\rho C_{\mu} \frac{k^{2}}{\varepsilon}
$$

\section{Geometry Mesh Generation}

Two-dimensional geometry has been adapted and meshed to create a grid for the $2 \mathrm{~m}$ height column. 


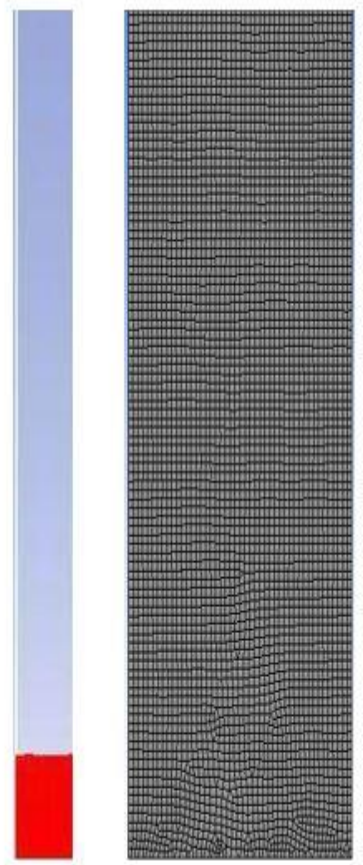

Figure 2: Tree Phase fluidized bed Mesh Model

\section{Boundary and Initial Conditions:}

Suitable and reasonable boundary conditions have to be implemented in the computational domain, to produce a well-defined equation system. The gas and liquid inlet velocity represent the inlet boundary condition whereas the atmospheric pressure is the outlet boundary condition; the no-slipping is considered condition. The solidsolid restitution coefficient is assumed to be 0.9 as a default value. Maximum iteration per time step is equal to 50 with time step size 0.01 .

\section{Results and Discussion:}

\section{Effect of Gas Velocity on Bed Height}

The experimental data that are shown in Figures 3 and 5 and the simulation data shown in Figures 4 and 6 illustrate the variation of bed height versus different superficial gas velocities at constant liquid velocity. With the increasing gas velocity the bed height increases and this bed expansion is observed for the two solid bed (catalyst and glass beads) as shown in these Figures, that the same influence for two solid beds.

It is noted that the bed expansion of catalyst is higher than that of glass bead because of the lower density of catalyst. 
Journal of University of Babylon for Engineering Sciences, Vol. (26), No. (6): 2018.

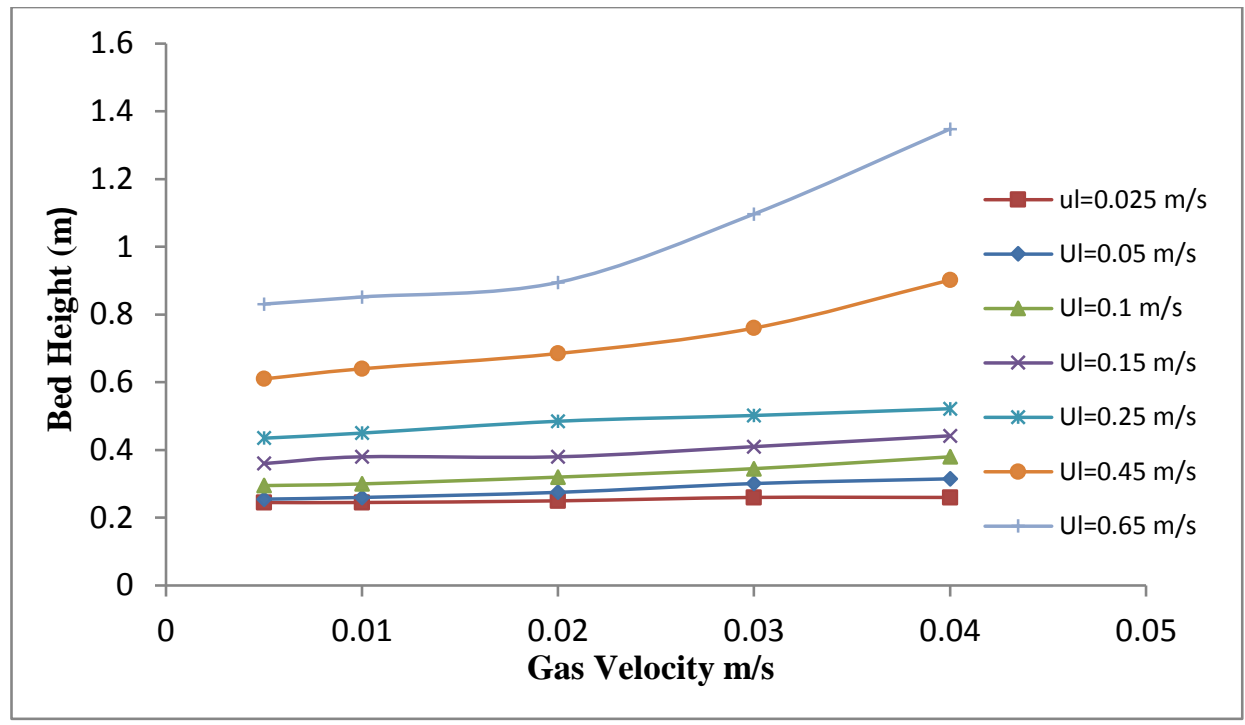

Figure 3: Experimental results showing the effect of gas velocity on the bed expansion for catalyst bed at different liquid velocities.

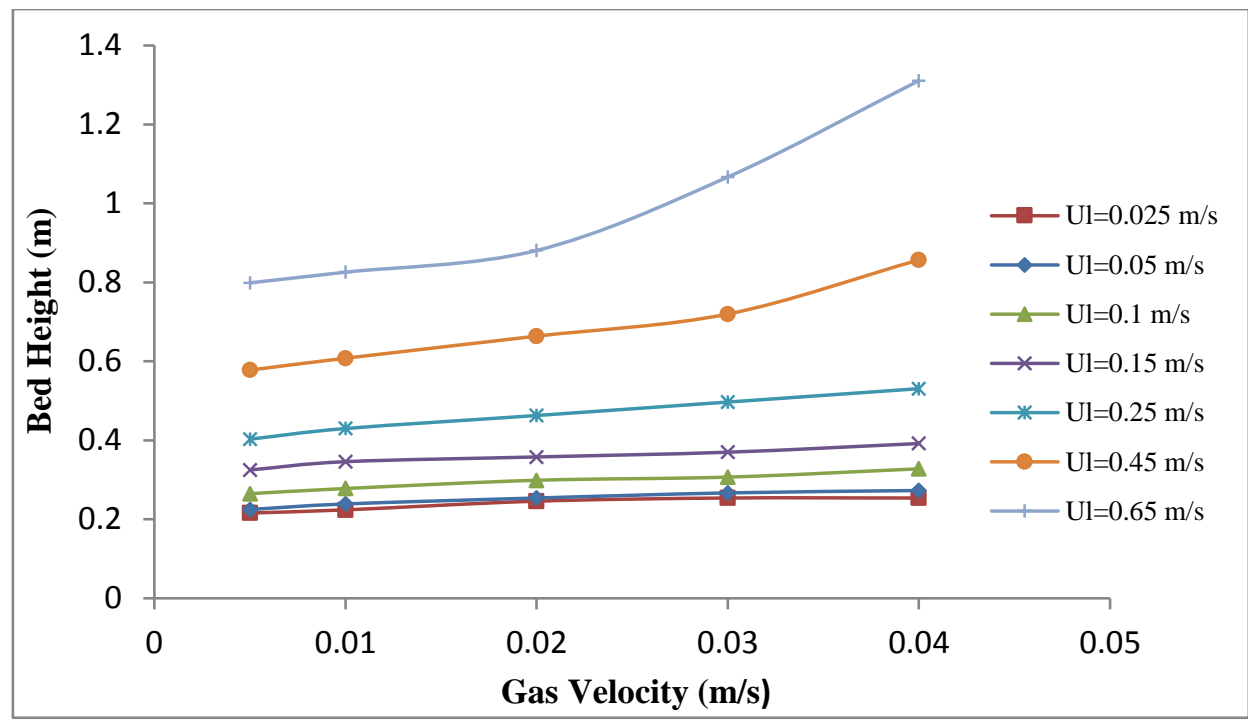

Figure 4: Simulation results showing the effect of gas velocity on the bed expansion for catalyst bed at different liquid velocities. 
Journal of University of Babylon for Engineering Sciences, Vol. (26), No. (6): 2018.

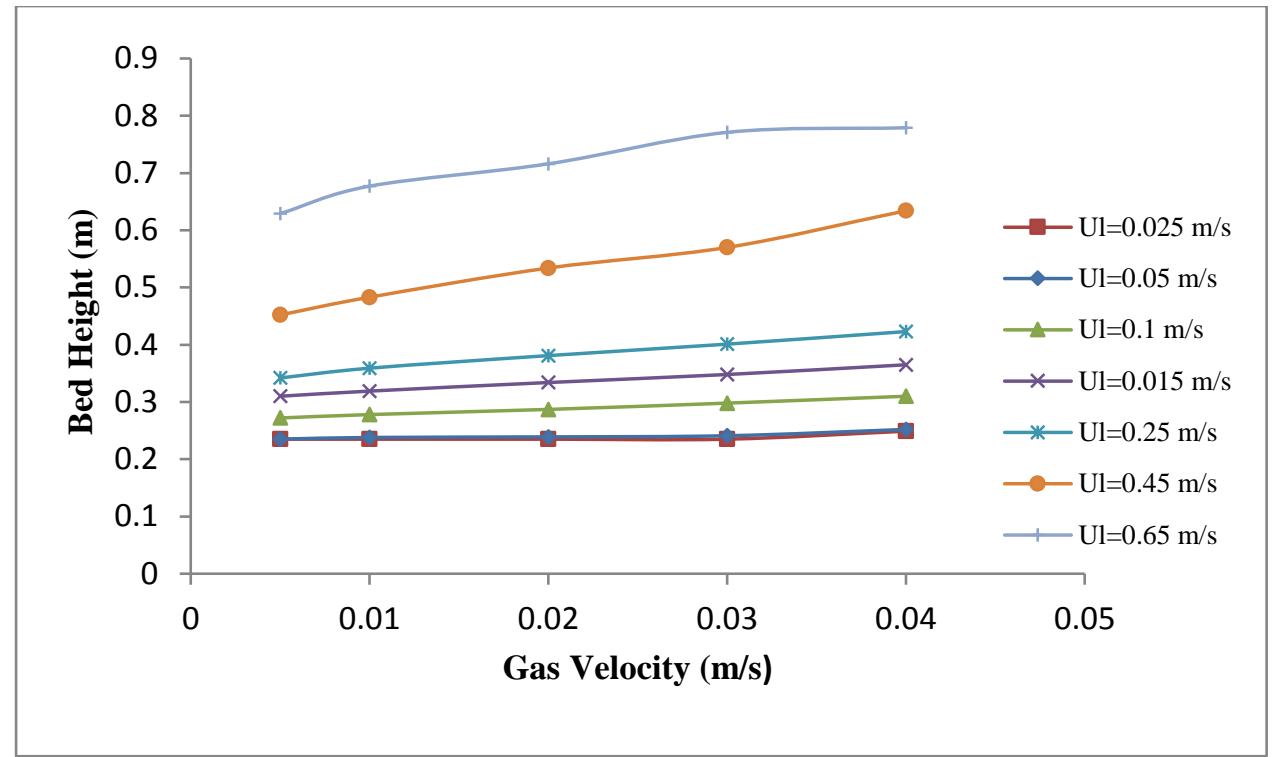

Figure 5: Experimental results showing the effect of gas velocity on the bed expansion for glass bead at different liquid velocities.

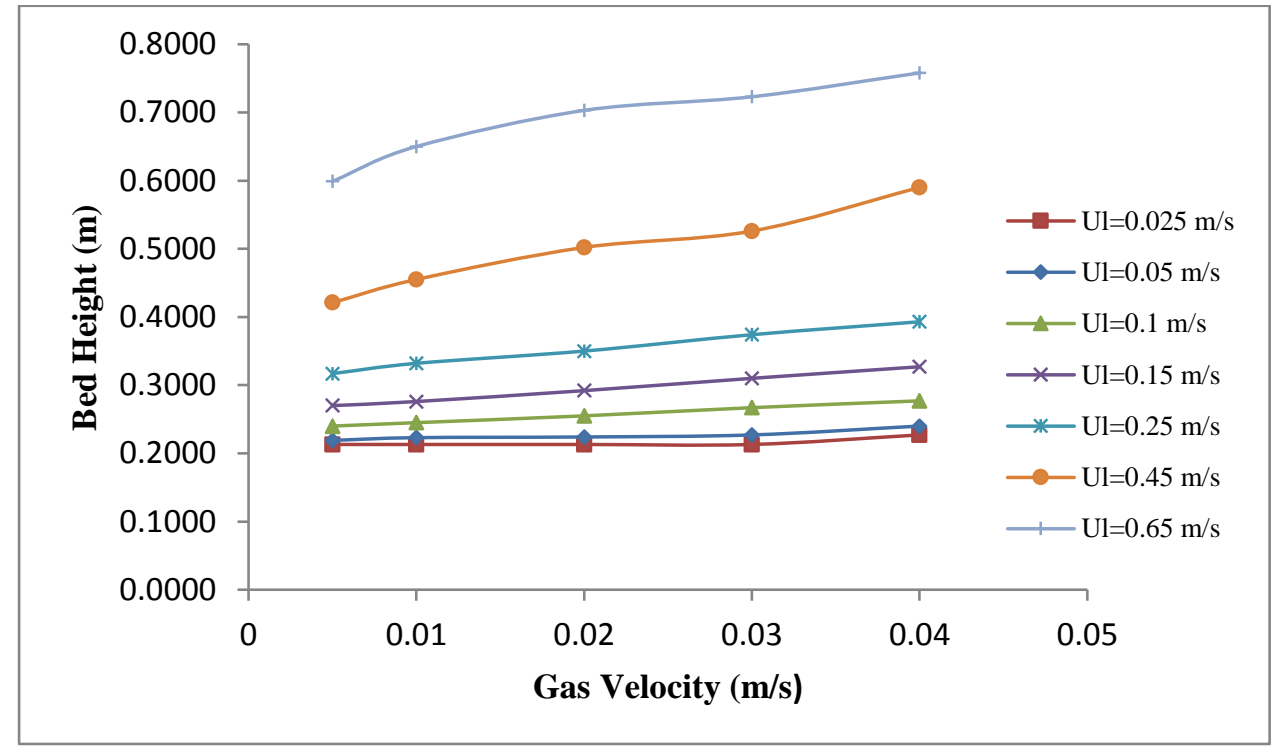

Figure 6: Simulation results showing the effect of gas velocity on the bed expansion for glass bead at different liquid velocities. 
Journal of University of Babylon for Engineering Sciences, Vol. (26), No. (6): 2018.
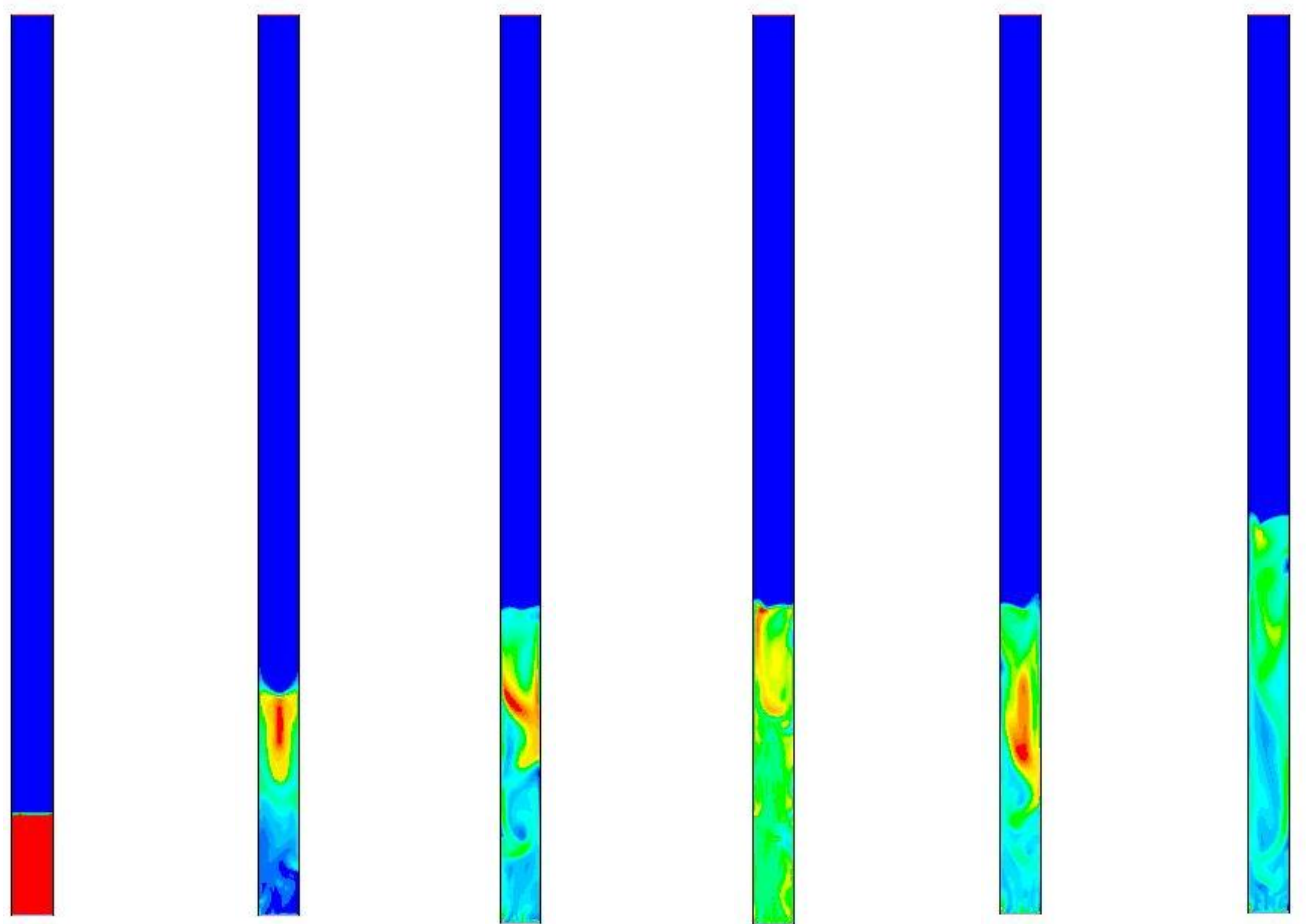

0 0.005 0.01 0.02 0.03 0.04

Figure 7: Effect of different gas superficial velocities on bed expansion at liquid superficial velocity is $0.45 \mathrm{~m} / \mathrm{s}$ for catalyst bed.
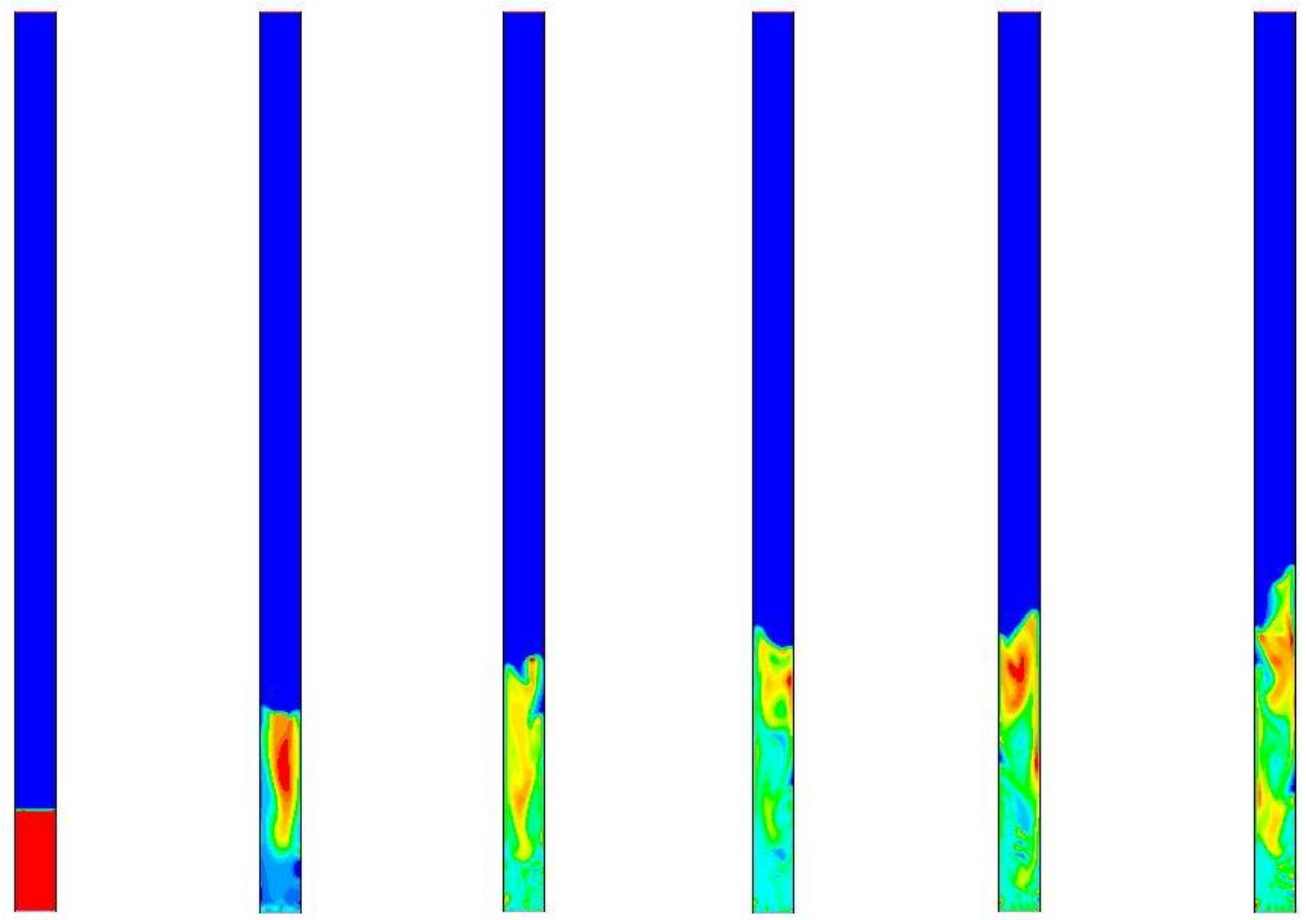
0
0.005

0.01

0.02

0.03

0.04

Figure 8: Effect different gas superficial velocities on the bed expansion at liquid superficial velocity are $0.45 \mathrm{~m} / \mathrm{s}$ for glass beads. 
Journal of University of Babylon for Engineering Sciences, Vol. (26), No. (6): 2018.

\section{Effect of Liquid Velocity on Bed Height}

The experimental results that are presented in Figures 9 and 11 and the results simulation that are shown in Figures 10 and 12 illustrate the relationship between the kerosene velocity and the bed height for catalyst bed and glass bead at different gas flow rates. It can be seen that the height of solid particle beds increased with increasing the kerosene velocity. The results are indicating that height of the expanded bed is a strong function of liquid velocity.

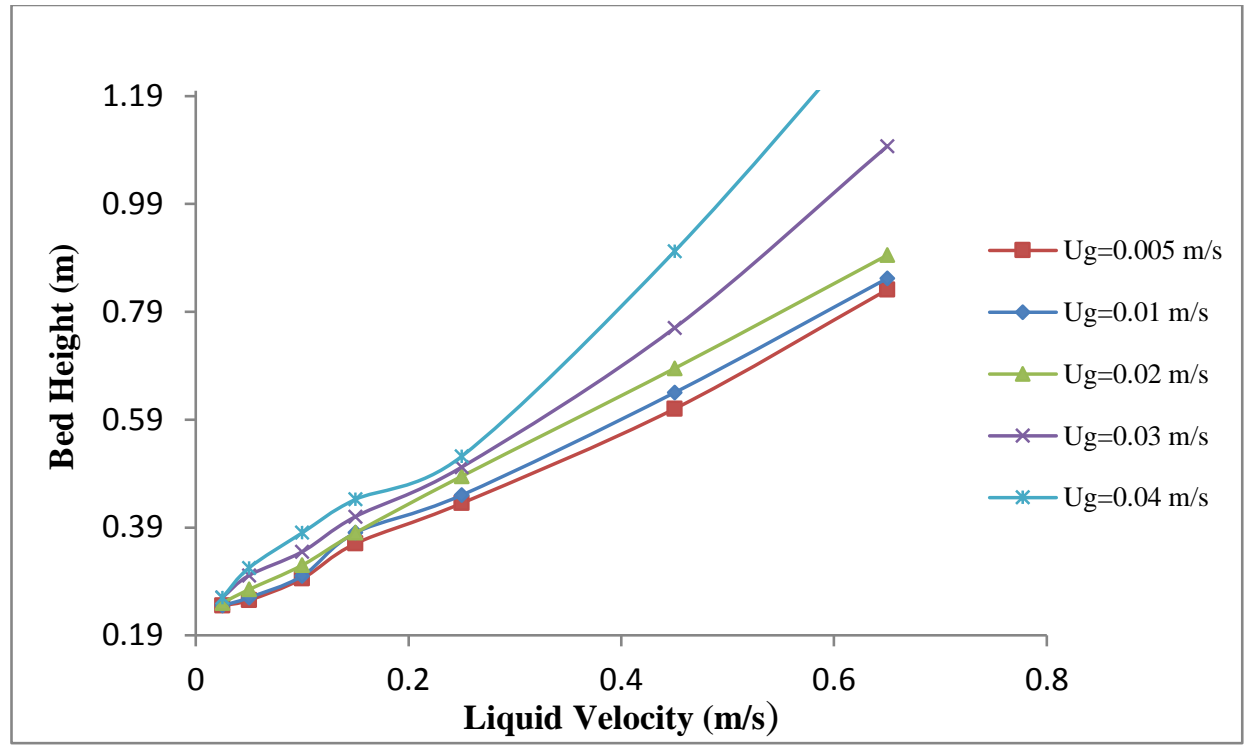

Figure 9: Experimental results showing the effect of liquid velocity on the bed expansion for catalyst at different gas velocities.

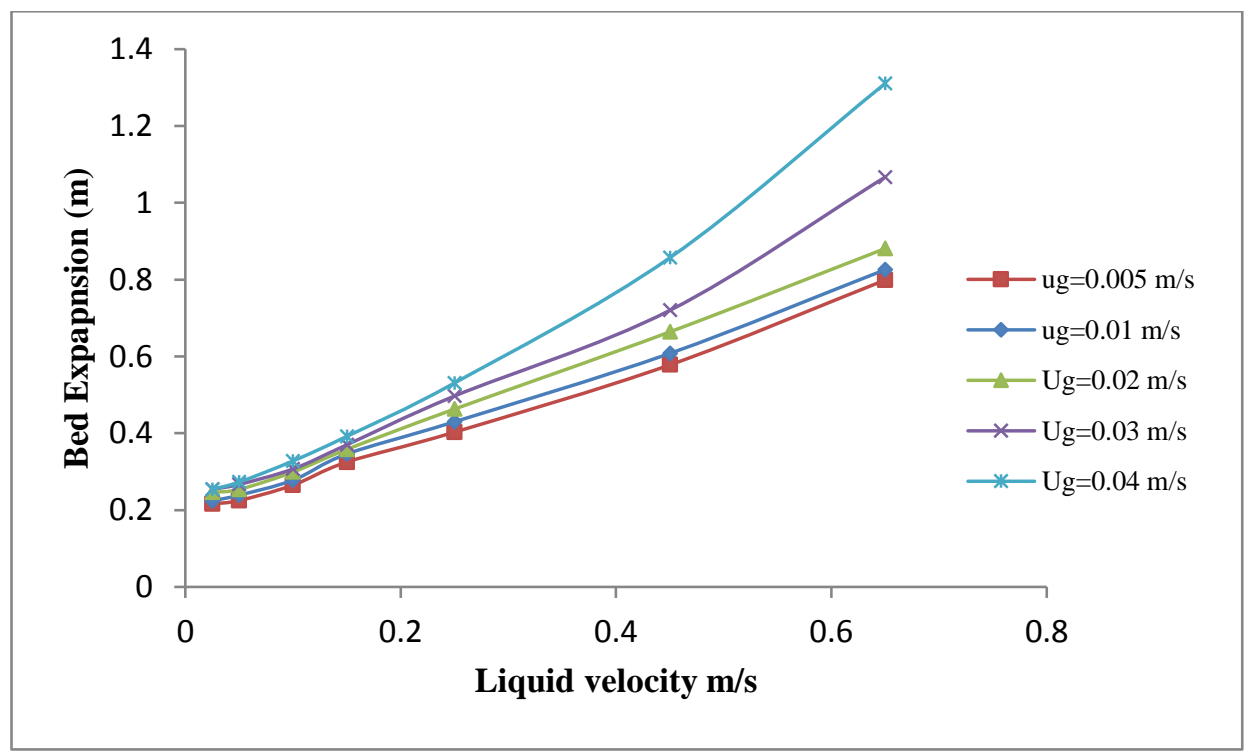

Figure 10: Simulation results showing the effect of liquid velocity on the bed expansion for catalyst at different gas velocities. 
Journal of University of Babylon for Engineering Sciences, Vol. (26), No. (6): 2018.

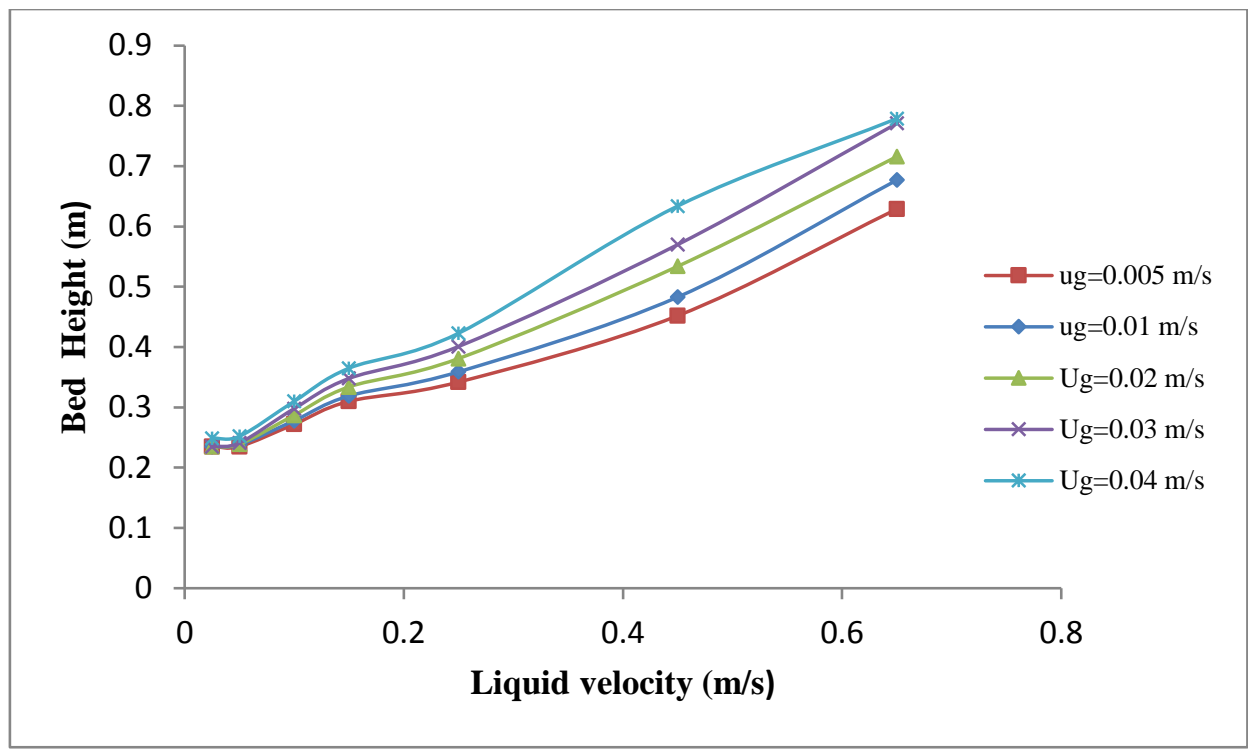

Figure 11: Experimental results showing the effect of liquid velocity on the bed expansion for glass beads at different gas velocities.

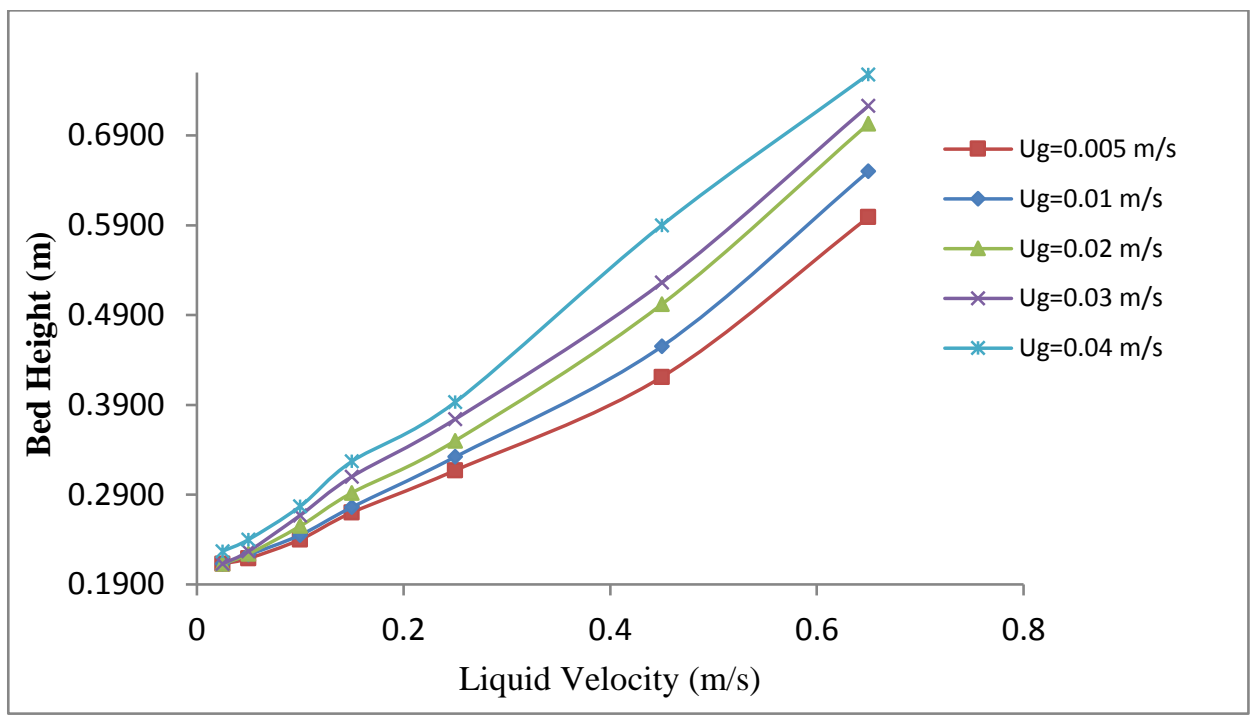

Figure 12: Simulation results showing the effect of liquid velocity on the bed expansion for glass beads at different gas velocities. 
Journal of University of Babylon for Engineering Sciences, Vol. (26), No. (6): 2018.
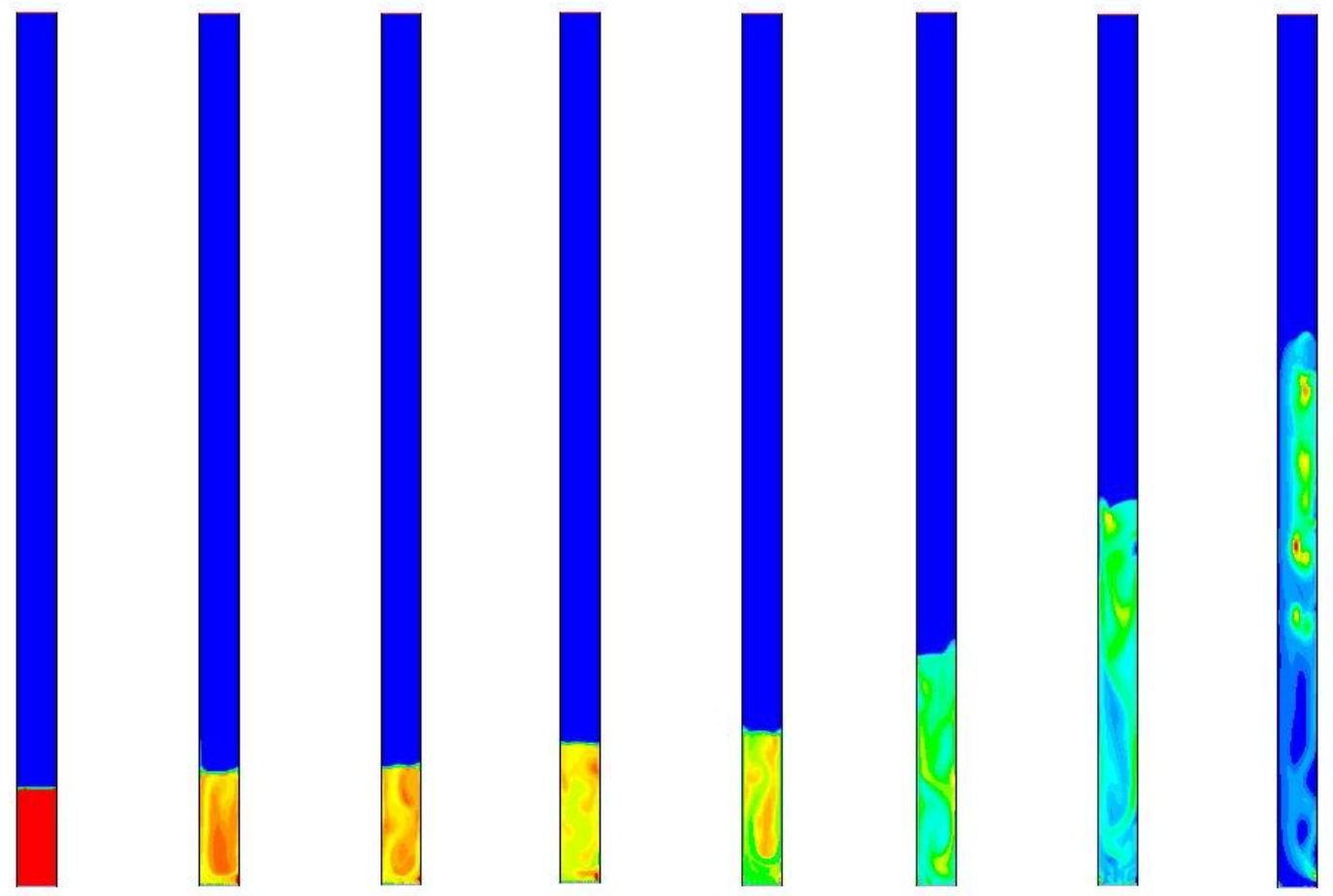

0

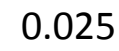

0.05

0.1

0.15

0.25

0.45

0.65

Figure 13.e: Effect of different liquid superficial velocities on bed expansion at gas superficial velocity is $0.04 \mathrm{~m} / \mathrm{s}$ for catalyst bed.

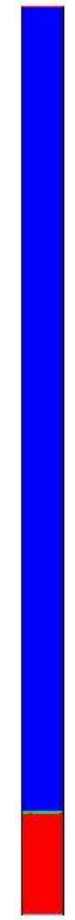

0

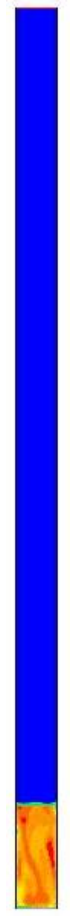

0.025

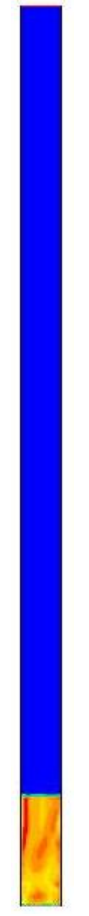

0.05

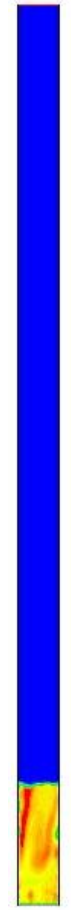

0.1

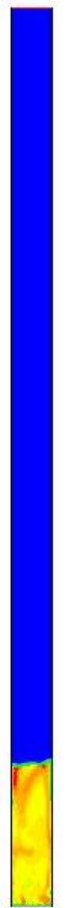

0.15

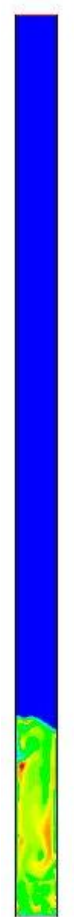

0.25
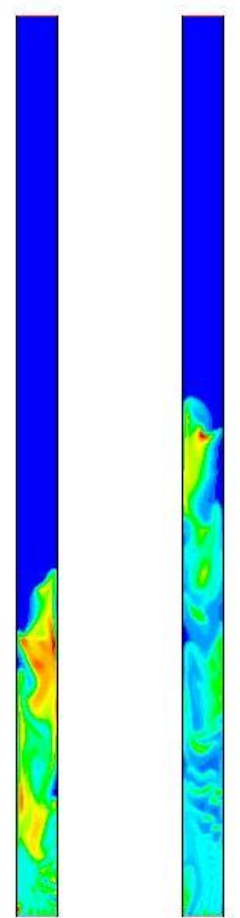

0.45

0.65

Figure 14: Effect of different liquid superficial velocities on bed Expansion at gas superficial velocity is $0.04 \mathrm{~m} / \mathrm{s}$ for glass beads. 
Journal of University of Babylon for Engineering Sciences, Vol. (26), No. (6): 2018.

\section{Validity of Simulation Results}

The experimental and simulations results were compared and the difference between them was very small due to the difference in velocity calibration of the liquid and gas, the solid particles used in the experiment have a wide diameters range whereas in the simulation all solid particles are assumed having the same diameter and the error that occurs in reading the bed height of the solid bed in the experimental work, as shown in the Figures 15 and 16.

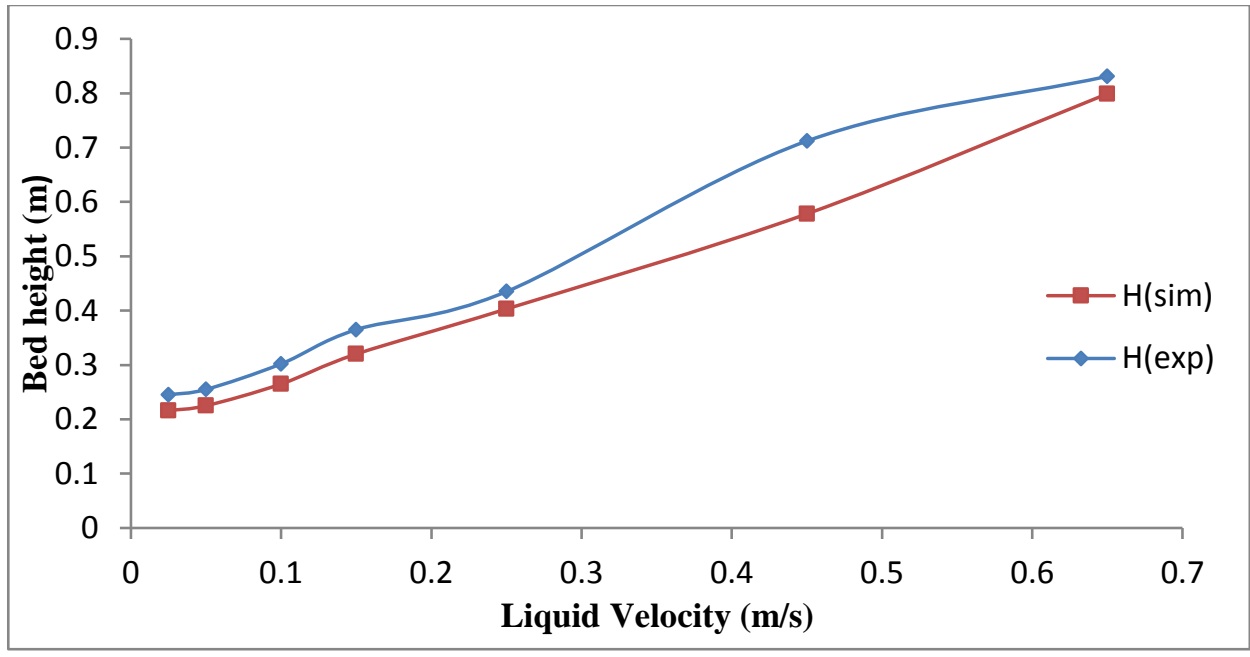

Figure 15: Comparison between experimental and simulation results for bed height of catalyst at gas velocity is $0.005 \mathrm{~m} / \mathrm{s}$.

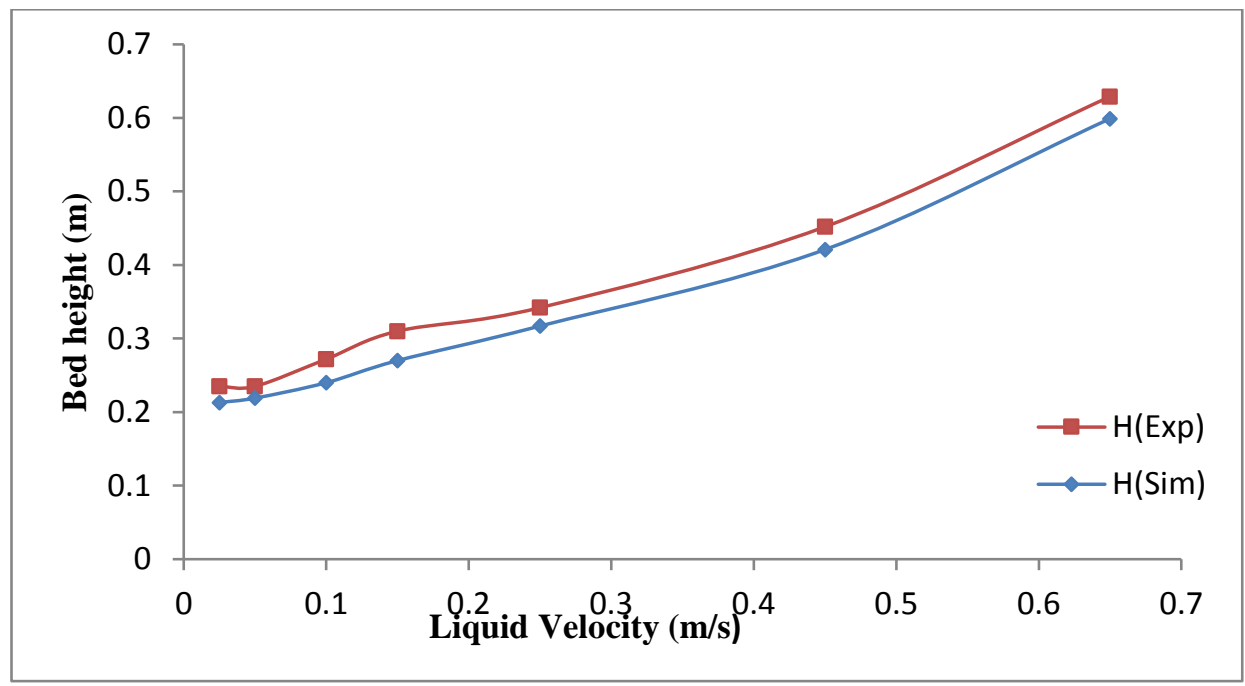

Figure 16: Comparison between experimental and simulation results for bed height of glass beads at gas velocity is $0.005 \mathrm{~m} / \mathrm{s}$.

\section{Conclusions}

The bed expansion increases, when gas and liquid velocities are increased, but it has observed that the increase is less when solid bed with high density was used.

\section{Acknowledgement}

I would like to thank the staff of University of Babylon for their assistance. 
Journal of University of Babylon for Engineering Sciences, Vol. (26), No. (6): 2018.

\section{Reference}

[1] Doyce Tesoro-Martinez, Tomas U. Ganiron Jr and Harold S. Taylor. , 2014, "Use of Fluidized Bed Technology in Solid Waste Management", International Journal, Vol.7, No 1

[2] Henrik, Heino. , 2015, "Particle movement and mixing in three-phase gas-liquidsolid fluidized bed", Department of Biotechnology and Chemical Technology, Thesis supervisor Prof. Ville Alopaeus.

[3] Bakker A., 2002, "Fluent introductory notes. Fluent Inc. "Lebanon".

[4] Anderson J. D., 1995, "Computational fluid dynamics". McGraw Hill, New York.

[5] Bahary M., 1994, "Experimental and computational studies of hydrodynamics in three-phase and two-phase fluidised beds", Ph.D. Thesis, Illinois Institute of Technology, Chicago.

[6] Mitra-Majumdar, D., Farouk, B., Shah, Y.T., 1997, "Hydrodynamic modeling of three- phase flows through a vertical column", Chem. Eng. Sci 52, $4485-4497$.

[7] Yali Tang, E. A. J. F. Peters, J. A. M. Kuipers, 2016. "Direct numerical simulations of dynamic gas-solid suspensions", AICH Journal,Volume 62, Issue 6,1958-1969.

[8] Bakker. , 2002, "Computational fluid dynamics lectures".

[9] User Guid of ANSYS FLUENT 16.0, (2016).

[10] Sato, H., 1981, "Attenuation of elastic waves in one-dimensional inhomogeneous elastic media", phys. Earth Planet. Inter., 26, 244-245.

[11] Gidaspow, D., 1994, "Multiphase Flow and Fluidization: Continuum and Kinetic Theory 55Descriptions", Academic Press, New ork.

[12] Launder and D. B. Spalding. , 1993, "Mathematical Models of Turbulence", Journal of Fluid Mechanics, volume 57, Issue 4. 
Journal of University of Babylon for Engineering Sciences, Vol. (26), No. (6): 2018.

\section{محاكاة سي اف دي وتوثيق النتائج لطبقة المادة الصلبة لعملية تمييع ثلاثي الطور زينب عبد الامير جودي زيدون محسن شكور عامر عزيز عبد الرحمن \\ قسم الهندسة الكيميائية، الجامعة النكنولوجية، بغد/د، العر/ق}

ameraa1972@yahoo.com dr_zaidoon@yahoo.com Zainababed13@gmail.com

\section{الخلاصة}

قد تمت دراسة الخصائص الهايدرودينامكية لعملية التميع لثناثي أطوار في هذا العمل. أجري العمل التجريبي في عمود البرسيكس بقطر 0.092 م وارتفاع (2). تم استخدام الكيروسين كطور مستمر والهواء كطور مشتت. استخدامت خرز الزئ فياج

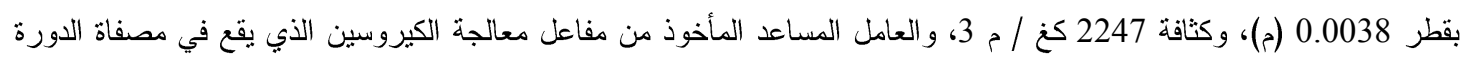
بقطر 0.0025 (م))، وكثافة 2070 كغم / م 3 كمادة صلبة.

قد ثم النحقق من نتائج (CFD) من الخصائص الديناميكية التي ثم الحصول عليها من المحاكاة مع النتائج التجريبية باستخدام أنسيز فلوئنت 16.0. أستخدم نهج التنفق الحبيبي لكتعدد المراحل يولريان والقادر على التنتؤ بالأداء العام لنظام ثلاثي اطوار من الغاز -السيائل-الصلب. أوضحت النتائج أن ارتفاع الطبقة الموسعة للمادة الصلبة ينأثر أكثر من تغييرات سرع السائل، فإنه يزيد مع زيادة سرعة

الكلمات المفتاحية: توسع السرير ، برج التميع لثلاث اطوار، دراسة الهيدروديناميكا، ديناميكية السو ائل الحسابية. 